\title{
Qualitative and Quantitative Phytochemical Analysis of Acacia Catechu Willd
}

\section{Priyanka Karande* Ashapak Tamboli, Swapnil More}

Department of Pharmaceutical Chemistry, Sahyadri College of Pharmacy, Methawade, Sangola, Maharashtra, India

*Corresponding Auther : Email Id - priyankakarande 32@gmail.com

\begin{abstract}
Acacia catechu willd has a great importance due to its medicinal properties. It is a historical plant; widely used in traditional medicine especially in Asia. Modern technology has made easy to study pharmacological properties of traditional medicine so great interests have been developed in historical traditional plants. There is a great use of Acacia catechu in dermatology and sore throat. Now a days antimycotic, hypoglycemic activity has also been reported. Phenols or polyphenols are the natural chemicals which are found in Acacia catechu. Phenolic compounds have similar basic structural chemistry as that of aromatic compounds and they contain a basic phenolic ring. They have an astringent effect and are widely used in tanning of lathers. They are also used in cancer treatment, dermatological disorders and possess anti-microbial activity. One of the most important feature of these compounds is their anti-oxidant effect. Due to the presence of these compounds in Acacia catechu willd; this plant has gained a vital role in medicinal use. In this paper, effort is made to sum up the researches which have been done on Acacia catechu willd which will be helpful to know that how many aspects of this plant are yet to be explored.
\end{abstract}

Keywords : Acacia Catechu Willd, Catechin, Flavonoids, Tanning, Alkaloids, Arachidonic Acid.

\section{INTRODUCTION}

Acacia catechu belongs to family Febaceae which is also called pea family or legume family due to presence of single chambered legume in all species of this family. Acacia catechu willd is a small to moderate sized plant widely distributed throughout Asia. The main origin of this plant is Pakistan, India, Thailand and Bangladesh. It contains polyphenolic components, tannins, alkaloids, carbohydrates, flavonoids and seeds of this plant are good source of protein. Catechin present in this plant plays a vital role as anti-oxidant. In vivo Catechins are extensively and rapidly metabolized and impart to its anti-oxidant property. It is very famous for its astringent and tanning effect. The most common use of this plant is in the treatment of sore throat[X, XI, XII].

\section{METHODS AND MATERIAL}

\section{Collection of plant material}

Fresh aerial parts of acacia catechu, used for the study was collected from the sangola resion, sangola district during August 2019. The plant was identified and Authenticated by Botanist DR. Tembhurnikar sir, Sangola Mahavidyalaya, sangola. The leaves of acacia catechu was shade dried and made the fine powder of the leaves and store in the polythene bags. 
phytochemical analysis : Qualitative phytochemical analysis of extract pet ether, Qualitative chloroform, ethyl acetate and ethanol carried out by following test :

\section{Test for alkaloid[XI]}

Mayers Test :

To $2 \mathrm{ml}$ liquid extract with add few drop of Mayer reagent formation of cream precipitation indicate the presence of alkaloid.

\section{Dragndroff's Test :}

To $2 \mathrm{ml}$ extract with add few drops of of Dragndroff's reagent to the formation of yellow precipitate which presence of alkaloid.

\section{Wagner's Test :}

To $2 \mathrm{ml}$ of extract with add few drop of Wagner's reagent to the test tube formation of reddish precipitate which indicate presence of alkaloid.

\section{Test For Carbohydrate[VIII] :}

Fehling's Test :

The extract was taken in a test tube then add $1 \mathrm{ml}$. of the Fehling's solution (A and B) was added and heat is boiling water bath. The solution was observed for the brick red precipitate.

Molisch's Test :

To extract, few drops of Molisch reagent was added and shake then add conc. Sulphuric acid from side of the test tube. Formation of a Violet ring at the junction of two liquid.

\section{Barfoed's Test :}

To the extract in the test tube, few drops of Barfoed's reagent was added and boiled on water bath for 1-2 minute. The solution was observed red ppt.

Benedict's Test :

Few drops of Benedict's reagent was added to the test solution in test tube and boiled on water bath for 5 minutes. Solution appears green, yellow, orange or red precipitate.

\section{Test For Flavonoid[VII]:}

Alkaline Test :

Extract was treated with few drop of sodium hydroxide solution. Formation of intense yellow colour, which becomes colorless on addition of dilute acid, indicated the presence of flavonoids.

Lead Acetate test:

Extract was treated with few drop of lead acetate solution. Formation of yellow colour precipitate which indicated the presence of flavonoid.

Shinoda Test :

To alcoholic solution of extract, a few fragment of magnesium ribbon and Conc. HCL were added. Appearance of magneta colour after few minutes indicated the presence of flavonoid.

\section{Test For Glycoside[XI] :}

Legals Test :

To extract in the testtube, add $1 \mathrm{ml}$ of pyridine and $1 \mathrm{ml}$. of sodium nitroprusside. Observe the pink colour appears which indicate the presence of glycosides. 


\section{Liebermanns Test :}

To $3 \mathrm{ml}$. extract in test tube, add a few drops of acetic anhydride and cooled. conc. Sulphuric acid was added along side of test tube. Formation of boiled brown ring at the junction indicated presence of glycoside.

Borntrager test:

To $3 \mathrm{ml}$. extract in test tube, add dilute sulphuric acid boil on water bath for $5 \mathrm{~min}$. cool and filtrate. Cold filtrate, add equal volume of benzene or chloroform. Shake well. Separate the organic solvent in separating funnel. Add ammonia ammonical layer turns pink or red which indicate the presence of glycoside.

\section{Test for sterol[VII] :}

Salkowskis Test :

The extract was taken in test tube then add $2 \mathrm{ml}$ of chloroform and $2 \mathrm{ml}$. of concentrated sulphuric acid. Shake well. chloroform layer manifestation red and acid layer form greenish yellow fluorescence indicated the presence of sterol.

Liebermann- Burchard Test :

To $2 \mathrm{ml}$. extract, add 1-2 ml. acetic anhydride and 2 drops of concentrated $\mathrm{H} 2 \mathrm{SO} 4$ from the side of the test tube. Initially red then blue and finally green colour appearance indicate the presence of sterol.

\section{Test For Triterpenes[VIII] :}

Salkowoskisw Test :

To extract were dissolved in chloroform, chloroform solution in test tube an add few drops of conc. Sulphuric acid shake well and allowed to stand. Formation of golden yellow colour indicate the presence of triterpenes.

\section{Liebermann-Burchard Test :}

To extract were dissolved in chloroform solution in test tube add few drops of acetic anhydride boiled and cooled conc. Sulphuric acid was added by the side of the test tube. Formation of brown ring indicate the presence of triterpenes.

\section{Test for saponin $[\mathrm{XI}]$ :}

\section{Foam test :}

The extract were diluted with $20 \mathrm{ml}$. distilled water, shaken vigorously and observed. Formation foaming indicated the presence of saponin.

Quantitative phytochemical analysis :

Determination of alkaloid :

Quantitative determination of alkaloid was carried out to the methodology by Ejikeme et al [III,IV,VII].Correctly $200 \mathrm{~cm} 3$ of $10 \%$ acetic acid in ethanol was added to each one leaves powder of sample ( $2.50 \mathrm{~g})$ in a beaker and allowable stand for 4hours. The extract was concentrated on a water bath to one- fourth of the original quantity followed by addition of 15 drop of concentrated ammonium hydroxide dropwise to the extract until precipitation was complete immediately later than filtrarion. Later 3 hours of mixture sedimentation, the supernatant was discarded and precipitates were washed with 20 $\mathrm{cm} 3$ of $0.1 \mathrm{M}$ of ammonium hydroxide and then filtered using Gem filter paper $(12,5 \mathrm{~cm})$. Using electronic weighing balance Model B-218 the residue was dried in an oven and percentage of alkaloid is expressed mathematically as :

Determination of saponin :

Quantitative determination of saponin was according to the methodology by Ejikeme et. Al.[III,IV] take a $250 \mathrm{~cm} 3$ conical flask and this flask pour into 100 cm3of $20 \%$ aqueous ethanol was added to $5 \mathrm{gm}$ of leaves powder sample. The mixture was heated on water bath 4 hour with continuous stirring at a temperature 55o C with constant stirring. Another re extracted residue mixture was $100 \mathrm{~cm} 3$ of $20 \%$ aqueous ethanol after filtration and heated for 4 hours 
at a constant temperature of $55 \mathrm{c}$ with constant stirring. These extract was combined and evaporated to $40 \mathrm{~cm} 3$ on water bath at 90 C. $20 \mathrm{~cm} 3$ diethyl ether was added to the concentrate in a $250 \mathrm{~cm} 3$ separator funnel and vigorously agitate from which the aqueous layer was taken and ether layer was discarded. This process purification was repeated twice. $60 \mathrm{~cm} 3$ of $n$ butanol was added and extracted twice $10 \mathrm{~cm} 3$ of $5 \%$ sodium chloride. After sodium chloride layer was discarded and remaining solution was heated on water bath for 30 minutes, later which solution was transferred into a crucible and was dried in an oven to a constant weight. The percentage of saponin was calculated as:

Determination of flavonoid :

Quantitative determination of flavanoid was carried out using the method reported by Ejikeme et al. Bohan and Kocipai[III] . Correctly $50 \mathrm{~cm} 3$ of $80 \%$ methanol was added to $2.50 \mathrm{~g}$ of leaves powder in 250 cm3 beaker, enclosed and allowed to stand for 24 hours at room temperature. After supernatant solution was discarded and residue was re extracted (three times) with the same quantity of ethanol. Filter the whole solution of each leaves sample was Whatman filter paper number 42 (125) was used.
Each leaves sample filtrate was later transferred into a crucible and evaporated to dryness on a water bath. The crucible was cooled in a desiccators weighed until constant weight was obtained. The percentage of saponin is expressed mathematically as :

\section{DISCUSSION AND RESULT}

When herb are used for treating certain ailment and disorder, phytochemicals are bioactive compound are responsible for its medicinal as well as physiological activities. Qualitative and quantitative phytochemical analysis of the present study revealed the presence of alkaloids, carbohydrates, flavonoids, saponin, triterpenoids, and glycosides. Alkaloid possess biological properties such as analgesic, antibiotic, antiplasmodic activity. Flavonoids are commonly used natural antioxidant having antimicrobial as well as anticarcinogenic activity. Saponin are characterized by formation of foam with aqueous solution and are known possess anti- inflammatory activity. Glycoside have cardio active drug and used for the treatment of cardiovascular disease. Quantitative estimation of total phenol and tannin revealed that there is significant presence of tannin and phenol in the plant extract while alkaloid are present in more amount.

Table 1. Qualitative chemical test of the different extract of aerial part of Acacia Catechu Willd

\begin{tabular}{|l|l|l|l|l|l|l|}
\hline $\begin{array}{l}\text { Chemical } \\
\text { constitue } \\
\text { nt }\end{array}$ & Test & $\begin{array}{l}\text { Petrolium } \\
\text { ether(60- } \\
80)\end{array}$ & Chloroform & $\begin{array}{l}\text { Ethyl } \\
\text { acetate }\end{array}$ & Ethanol & $\begin{array}{l}\text { Aqueou } \\
\text { s } \\
\text { extract }\end{array}$ \\
\hline \multirow{4}{*}{ Alkaloid } & Meyer test & $-\mathrm{ve}$ & $+\mathrm{ve}$ & $-\mathrm{ve}$ & $-\mathrm{ve}$ & $-\mathrm{ve}$ \\
\cline { 2 - 7 } & $\begin{array}{l}\text { Dragendroff } \\
\text { s test }\end{array}$ & $+\mathrm{ve}$ & $+\mathrm{ve}$ & $+\mathrm{ve}$ & $+\mathrm{ve}$ & $+\mathrm{ve}$ \\
\cline { 2 - 7 } & Wagner test & $-\mathrm{ve}$ & $-\mathrm{ve}$ & $-\mathrm{ve}$ & $-\mathrm{ve}$ & $-\mathrm{ve}$ \\
\cline { 2 - 7 } & & & & & & \\
\hline \multirow{4}{*}{ Carbohydrate } & Fehling's test & $-\mathrm{ve}$ & $-\mathrm{ve}$ & $-\mathrm{ve}$ & $-\mathrm{ve}$ & $-\mathrm{ve}$ \\
\cline { 2 - 7 } & Molisch test & $-\mathrm{ve}$ & $-\mathrm{ve}$ & $-\mathrm{ve}$ & $-\mathrm{ve}$ & $+\mathrm{ve}$ \\
\cline { 2 - 7 } & Barfoerd's test & $+\mathrm{ve}$ & $-\mathrm{ve}$ & $-\mathrm{ve}$ & $-\mathrm{ve}$ & $-\mathrm{ve}$ \\
\cline { 2 - 7 } & Benedict's test & $+\mathrm{ve}$ & $-\mathrm{ve}$ & $-\mathrm{ve}$ & $-\mathrm{ve}$ & $-\mathrm{ve}$ \\
\hline
\end{tabular}




\begin{tabular}{|l|l|l|l|l|l|l|}
\hline \multirow{5}{*}{ Flavonoid } & Shinoda test & $-\mathrm{ve}$ & $-\mathrm{ve}$ & $-\mathrm{ve}$ & $-\mathrm{ve}$ & $+\mathrm{ve}$ \\
\cline { 2 - 7 } & Lead acetate test & $+\mathrm{ve}$ & $-\mathrm{ve}$ & $-\mathrm{ve}$ & $-\mathrm{ve}$ & $+\mathrm{ve}$ \\
\cline { 2 - 7 } & Alkaline test & $+\mathrm{ve}$ & $+\mathrm{ve}$ & $+\mathrm{ve}$ & $+\mathrm{ve}$ & $+\mathrm{ve}$ \\
\hline \multirow{5}{*}{ Glycoside } & Legal test & $-\mathrm{ve}$ & $+\mathrm{ve}$ & $+\mathrm{ve}$ & $-\mathrm{ve}$ & $+\mathrm{ve}$ \\
\cline { 2 - 7 } & Borntrager test & $-\mathrm{ve}$ & $-\mathrm{ve}$ & $-\mathrm{ve}$ & $-\mathrm{ve}$ & $-\mathrm{ve}$ \\
\cline { 2 - 7 } & $\begin{array}{l}\text { Liebermann' } \\
\text { s test }\end{array}$ & $+\mathrm{ve}$ & $-\mathrm{ve}$ & $+\mathrm{ve}$ & $+\mathrm{ve}$ & $+\mathrm{ve}$ \\
\hline \multirow{5}{*}{ Sterol } & Salkowski test & $+\mathrm{ve}$ & $-\mathrm{ve}$ & $-\mathrm{ve}$ & $-\mathrm{ve}$ & $-\mathrm{ve}$ \\
\cline { 2 - 7 } & $\begin{array}{l}\text { Lieberman } \\
\text { Triterpenoids }\end{array}$ & $-\mathrm{ve}$ & $-\mathrm{ve}$ & $+\mathrm{ve}$ & $-\mathrm{ve}$ & $+\mathrm{ve}$ \\
\cline { 2 - 7 } & Salkowski's test & $+\mathrm{ve}$ & $-\mathrm{ve}$ & $-\mathrm{ve}$ & $-\mathrm{ve}$ & $-\mathrm{ve}$ \\
\hline Saponin & Lieberman's test & $+\mathrm{ve}$ & $-\mathrm{ve}$ & $+\mathrm{ve}$ & $-\mathrm{ve}$ & $+\mathrm{ve}$ \\
\hline
\end{tabular}

Table 2. Qualitative composition of Acacia Catechu

\begin{tabular}{|l|l|}
\hline Parameter & $\%$ yield \\
\hline Test for alkaloid & 8.97 \\
\hline
\end{tabular}

\begin{tabular}{|l|l|}
\hline Test for flavonoid & 4.8 \\
\hline Test for saponin & 7.2 \\
\hline
\end{tabular}

\section{IV.CONCLUSION}

Thus from the present study, the extract of A. catechu leaves possess different varieties of phytochemicals such as alkaloid, carbohydrates, saponin, triterpenoid, glicosides and steroids. The study revealed the basis of its use as folk medicine against various disease due to presence of these phytochemicals as bioactive compound. So, the plant extract can be utilized for further investigation.

\section{ACKNOWLEDGEMENT}

The authors wish to acknowledge Dr. Patil M. S Principle Sahyadri college of pharmacy and Asso. Prof Tamboli A. Head of department of pharmacy(chemistry), for the facilities provided to complete this research work.

\section{REFERENCES}

[1]. Chopra R.N., Nayer S.C., and Chopra I.C, Glossary of Indian Medicinal Plants, CSIR, New Delhi. pp42(1956).

[2]. C. H. Manjula and K. Ammani, "Phytochemical analysis and pharmacological importance of Sophora interrupta leaves,"International Journal of Research in Pharmaceutical and Biomedical Sciences, vol.3,no.4,pp.1798-1804,2012.

[3]. C.M.Ejikeme, C.S.Ezeonu, and A.N.Eboatu ,"Determination of physical and phytochemical constituents of some tropical timbers indigenous to Niger Delta Area of Nigeria," European ScientificJournal,vol.10,no.18,pp.247-270,2014.

[4]. D. E. Okwu, "Phytochemicals and vitamin content of indigenous spices of South Eastern Nigeria," Journal of Sustainable Agriculture and the Environment,vol.6,pp.30-34,2004.

[5]. D. J. Lefer and D. N. Granger, "Oxidative stress and cardiac disease," The American Journal of Medicine, vol. 109, no. 4, pp. 315-323,2000.

[6]. Gopalan C., Sastri B.V.R., Balasubramaniam S.C., Nutritive value of Indian foods. NIN, Hyderabad, India. (1991). 
[7]. Harborne, J.B (1973): Phytochemical Methods: A Guide to Modern Techniques of Plant Analysis. Chapman A \&Hall.London. Pp 279.

[8]. Khandelwal K.R. Practical Pharmacognosy, Nirali Prakashan. Pp.149-155(1995)

[9]. Kokate C.K., Purohit A.P., Gokhale S.B., Pharmacognosy. Nirali Prakashan. pp 6.16-6.17 (2009).

[10].Lakshmi, T, Geetha, R. V., \& Roy, Anitha, (2011). In vitro evaluation of antibacterial activity of heartwood extract of acacia catechu willd. International Journal of Pharma \& Bio Sciences. 2(2) pB.188.

[11].P. Kittakoop, C. Mahidol, and S. Ruchirawat, "Alkaloids as important scaffolds in therapeutic drugs for the treatments of cancer, tuberculosis, and smoking cessation "Current Topicsin MedicinalChemistry,vol.14,no.2,pp.239252,2014.

[12]. T. P. T. Cushnie, B. Cushnie, and A. J. Lamb, "Alkaloids: an overview of their antibacterial, antibiotic-enhancing and antivirulence activities," International Journal of Antimicrobial Agents,vol.44,no.5,pp.377386,2014.

[13]. Trease, G.E and Evans, W.C (1989a): A Textbook of Pharmacognosy. Bailliere Tindall Ltd, London; Pp.53

[14]. Lakshmi, T, Geetha, R. V., \& Roy, Anitha, (2011). In vitro evaluation of antibacterial activity of heartwood extract of acacia catechu willd. International Journal of Pharma \& Bio Sciences. 2(2) pB.188.

[15]. P. Kittakoop, C. Mahidol, and S. Ruchirawat, "Alkaloids as important scaffolds in therapeutic drugs for the treatments of cancer, tuberculosis, and smoking cessation "Current Topicsin MedicinalChemistry,vol.14,no.2,pp.239-

252,2014 .

[16]. T. P. T. Cushnie, B. Cushnie, and A. J. Lamb, "Alkaloids: an overview of their antibacterial, antibiotic-enhancing and antivirulence activities," International Journal of Antimicrobial Agents,vol.44,no.5,pp.377386,2014.

[17]. Scartezzini P., Antognoni F., Raggi M.A., Poli F., and Sabbioni C.,Vitamin C content and antioxidant activity of the fruit and of the Ayurvedic preparation of Emblica officinalis Gaertn . J Ethnopharmacol . pp104: 113-118 (2006).

[18]. Scartezzini P., Antognoni F., Raggi M.A., Poli F., and Sabbioni C.,Vitamin C content and antioxidant activity of the fruit and of the Ayurvedic preparation of Emblica officinalis Gaertn . J Ethnopharmacol · pp104: 113-118 (2006).

\section{Cite this article as :}

Sh Priyanka Karande, Ashapak Tamboli, Swapnil More, "Qualitative and Quantitative Phytochemical Analysis of Acacia Catechu Willd", International Journal of Scientific Research in Science and Technology (IJSRST), Online ISSN : 2395-602X, Print ISSN : 2395-6011, Volume 7 Issue 3, pp. 327-332, May-June 2020. Available at doi : https://doi.org/10.32628/IJSRST207349 Journal URL : http://ijsrst.com/IJSRST207349 